\title{
Profit Indices in Nile tilapia (Oreochromis Niloticus L.) Fed on Peanut-Based Meals as Alternatives to Dietary Fishmeal in Grow- Out Earthen Ponds
}

\author{
Musita A. A. ${ }^{1, *}$, Ogello E. O. ${ }^{1}$, Balirwa J. S. ${ }^{2}$, Bassa S. ${ }^{2}$ \\ ${ }^{1}$ Department of Fisheries and Natural Resources, Maseno University. ${ }^{2}$ National Fisheries \\ Resources Research Institute \\ *Corresponding author. @ apollomusita3000@gmail.com
}

\begin{abstract}
Persistence of dietary fishmeal probably accounts for the low profitability in farmed Nile tilapia in Uganda. A 24 week field study was conducted in Busoga sub-region of Eastern Uganda to compare profit indices in pond cultured Nile tilapia fed on peanut-based meals as alternatives to dietary fishmeal. It consisted of an experiment and sample survey that targeted fish biomass production and input-output valuation respectively. Each of the 12 earthen ponds measuring 12 cubic meters were stocked with 48 'all male' Nile tilapia (Oreochromis niloticus L.) fingerlings of mean initial weight of 21.7 grams. Iso-nitrogenous diets containing $30 \%$ and $25 \%$ Crude Protein were applied for the first eight and last four respectively. Dietary treatments included fishmeal-based diet and two peanut-based diets; peanut meal-based diet and mixed plant-based diet. Profit indices for the fishmeal and mixed plant-based- diets were not significantly different $(p>0.05)$. On the contrary, the Profit index characteristic to the PNM-based diet was significantly lower $(p \leq 0.05)$ than the other test diets. Accordingly, the mixed plant meal should be used for complete substitution of dietary fishmeal in pond cultured Nile tilapia.
\end{abstract}

Keywords: Nile tilapia, Peanut-based diets, Profit indices.

\section{Introduction}

Fishmeal is the commonest protein source in aqua feeds in many countries (Schmidt et al., 2016). The ingredient has consistently been applied as a sole protein in fish feed. The prevalence of dietary fishmeal in farmed fish is attributed to its high production performance. The efficiency of fishmeal in terms of growth (Coyle et al., 2004; Olfasen, 2006) and yield (Miles .and Chapman, 2006) in cultured species is a reflection of its unique combination of nutritional characters. High palatability and digestibility (Liti et al., 2006), desirable amino acid profile (Olfasen, 2006) and perfect balance of nutrients (Rust et al., 2012) that characterize dietary fishmeal are seldom expressed by alternative protein sources. Subsequently, the peculiarity of dietary fishmeal accounts for its superiority in terms of fish production. 
Despite the unrivalled biological performance of fishmeal in cultured fish, Ngugi et al. (2016) and Mmanda (2020) revealed that high price has reduced its popularity fish diets. Smallholder Nile tilapia farmers in Uganda cannot afford the fishmeal-based feed (Aanyu and Graber, 2010). High inclusion of the expensive fishmeal in aqua feed implies increased feed cost and reduced profitability. Since the reliance on fishmeal is among the economic concerns in aquaculture (Schmidt et al. 2016), replacement of the feed component with cheaper alternatives is increasingly becoming inevitable. Subsequently, search for economical alternatives to dietary fishmeal has been intensified (Agbo et al., 2011) in herbivorous species particularly Nile tilapia (El-Sayed, 2006).

Plant-based diets have consistently been tested as substitutes to dietary fishmeal. The high supply of crop products on farmsteads (Gillespie (2004) increased their preference in the diet of farmed Nile tilapia. Since wild vegetation has been threatened by intensification of human activities (Moehl and Hawart, 2005), aqua feed formulation is expected to resort to crop-derived resources. Irrespective of their competitive alternative uses, crop products are increasingly becoming dominant in fish feed formulations. Cotton seed meal (Mbahinzireki, 1999), soybean (Nordahl \& Pickering, 2004) peanut meal (Yidrim et al., 2014) and sunflower meal (Merica et al., 2015) have been tested as fishmeal alternatives in fish diets. Among the crop resources, only SBM was comparable to dietary fishmeal in terms of production performance (Dersjant-Li, 2002; Nordahl \& Pickering, 2004). Low supply and multiple usages rendered dietary SBM less economical in Uganda (Agricultural Planning Department, 2010). Subsequently, fishmeal has persisted of in the diets of cultured fish. According to FAO (2009), aquaculture's dependency on dietary fishmeal is risky if an alternative is not found.

Peanut have rarely been included in fish diets (El-Sayed and Gaber, 2003; Yildrim et al., 2014) despite their advantages relative to other oil seed meals; higher quantities locally produced in Uganda (Agricultural Planning Department, 2010), high palatability (Health and Nutrition research, 2010) coupled with elevated phosphorus level (Peanut Institute, 2003). The restriction on inclusion of peanut products due to aflatoxin contamination (Russa and Yanong, 2002) became invalid. According to Bainempaka, (2006), aflatoxins are not limited to peanuts since they are capable of attacking any oilseed meal stored under dirty and humid conditions. Although peanut meal was included as sole protein source in in the Nile tilapia diet (Yildrim et al., 2014), it induced poor fish growth due to amino acid deficiencies. According to Kaushik and Seliez (2010), improved feed performance is possible following the perfect combinations of plant-derived proteins

The majority of fish feeding trials have focused on levels of fish production (Bob-manuel and Erondu, 2010) without regard to the corresponding cost of production. The economics of fish production should be considered in feeding trials (El-Sayed, 2006) in order to assess farm profitability. According to The Fish Site (2008), cost-effectiveness is the challenge associated with substituting dietary fishmeal by plant proteins. Profit Index (PI) that relates value of farm output to cost of feed input (El-Saidy and Graber, 2003) is the appropriate tool for comparing profitability among test diets. Therefore, the main objective of the current study is to compare Profit Indices in Nile tilapia fed on peanut-based meals as alternatives to dietary fishmeal in pond cultured Nile tilapia. 


\section{Materials and Methods}

\section{Study Area}

The study was conducted in Busoga sub-region of Eastern Uganda located $0^{\circ} 30^{\prime}-1^{\circ} 00^{\prime}$ North, $33^{\circ} 00^{\prime}-34^{\circ} 00^{\prime}$ East (The comprehensive Atlas, 2015). It covered the experimental and survey sites. An experiment was conducted at Busoga University farm land in Iganga district. The experimental site consisted of freshly constructed earthen ponds (Plate 1). A 16 week feeding trial (March to July 2016) captured data on fish biomass production in the pond units. Individual and stock weight gains induced by test were measured on-site.

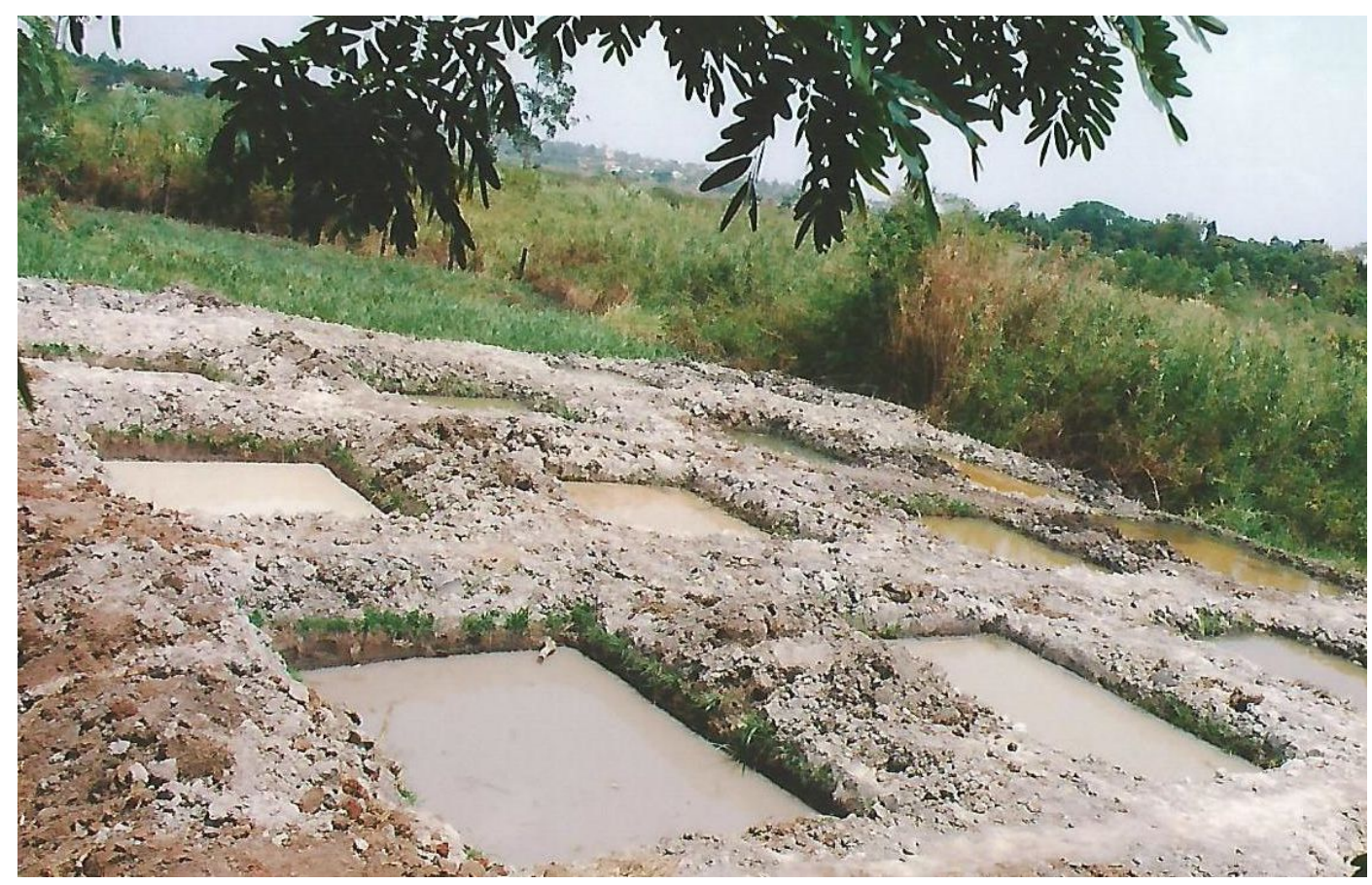

Plate 1. Earthen ponds at the experimental site

Sample surveys were conducted in survey sites A and B. Basing on local market prices, the former and latter aimed at input and output valuations respectively. The survey at site A coincided with the 16 week experiment. It aimed at determining costs of test feeds basing on local market prices of constituent ingredients. The three commodity markets and feed ingredients sold are indicated (Figure 1). 


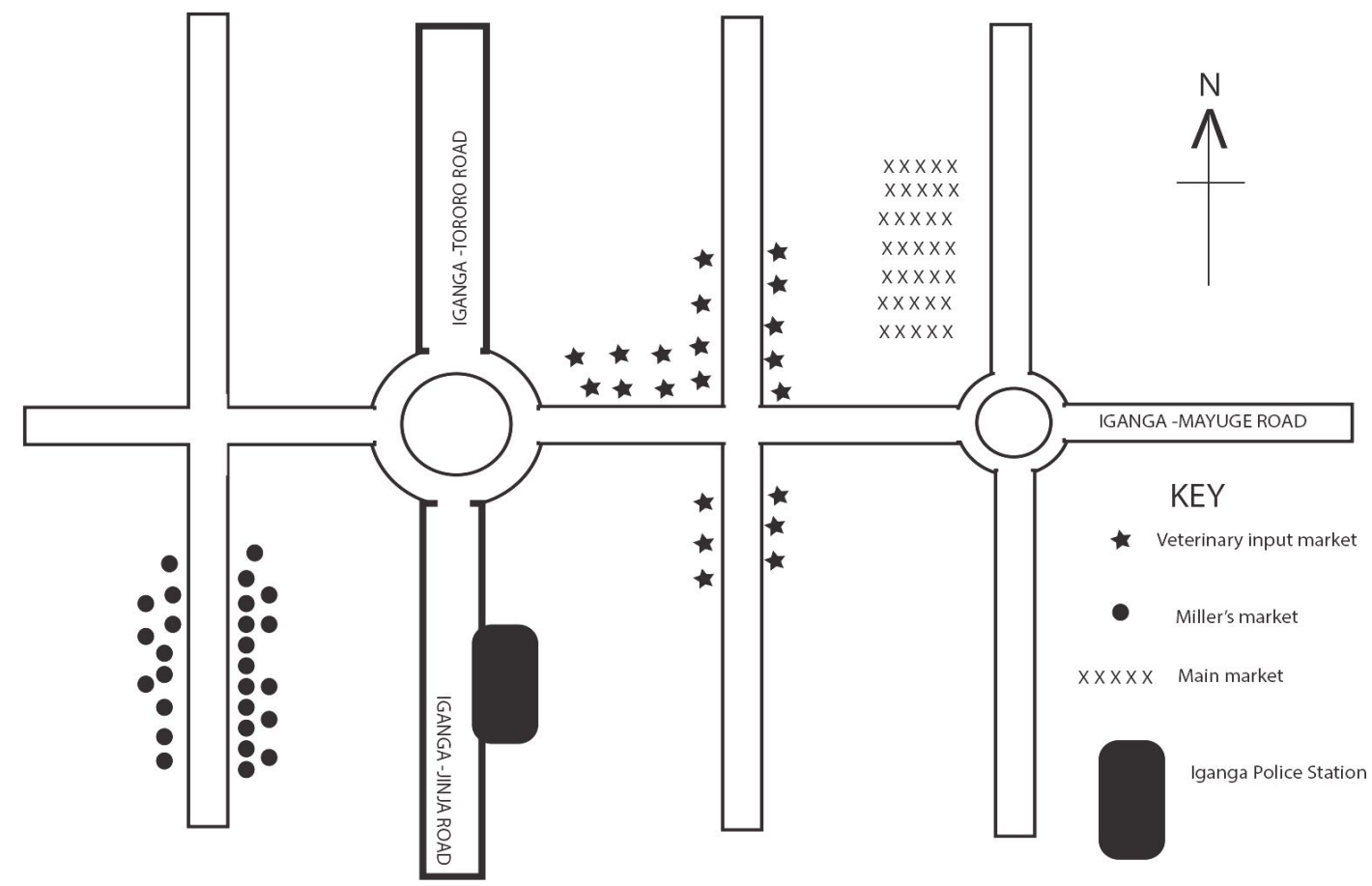

Figure 1. Commodity markets at survey site A at Iganga Municipality

A road network of rotating tar marked (all weather) and non-tar marked roads within Busoga sub-region constituted the survey site B (Figure 2).

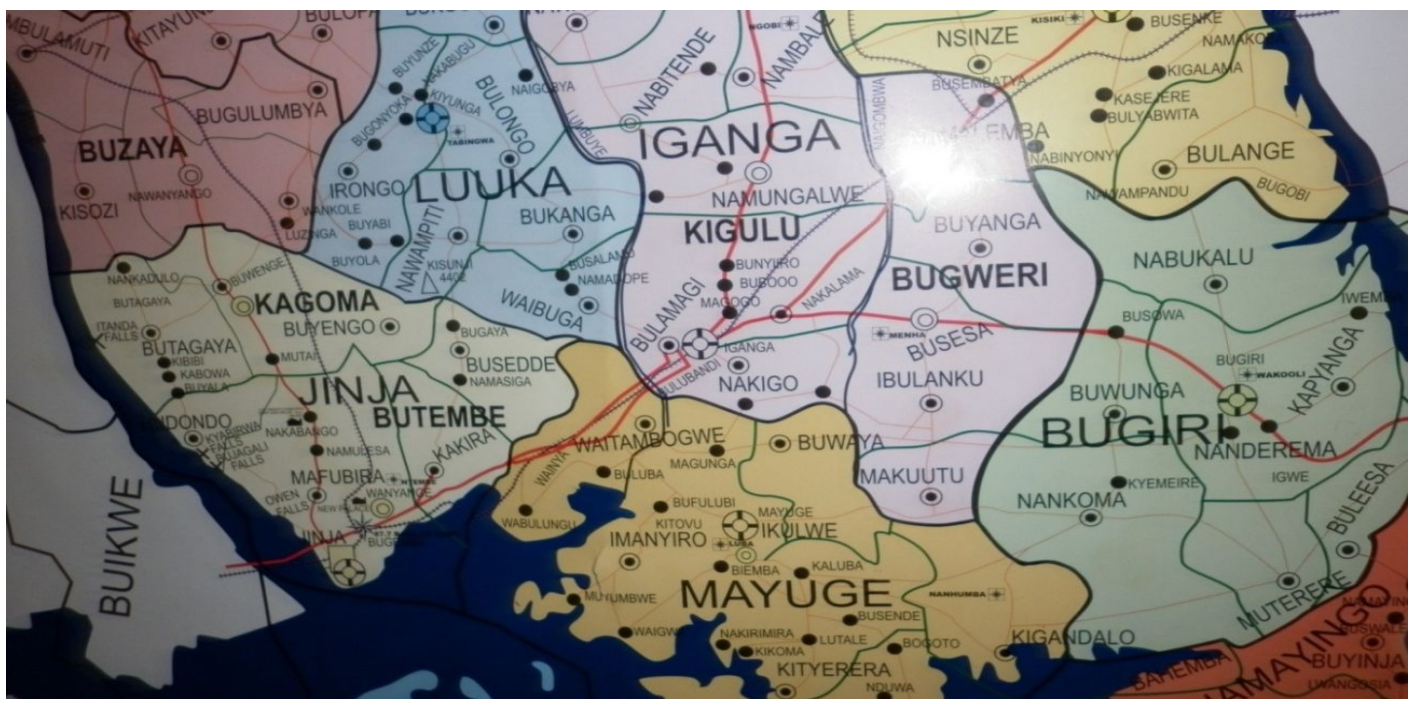

Figure 2. Trading centres along the main roads network of Busoga sub-region Source: UNRA (2015) 
The road network was characterized by linearly arranged trading centres; Namayingo, Bugiri, Nakivumbi, Mayuge, Musita Magamaga, Bugembe, Mafubira, Buwenge, Kamuli, Namwendwa, Kaliro, Busembatia, Namutumba, Busesa. A sample survey was conducted at the field site after the experiment from January to March 2017. Sampling units at survey site B indirectly valuated the experimental fish fed on the different test diets.

\section{Study Design}

There was variation in design in order to cater for data capture at the experimental and nonexperimental study sites. The experimental design aimed at capturing data on biomass production in different dietary treatment groups. Twelve rectangular-shaped earthen ponds measuring $4.0 \times 3.0 \times 1.0$ cubic meters for length, width and depth respectively, were established at the experimental site. The pond units were stocked at a density 48 Nile tilapia (Oreochromis niloticus L.) fingerlings. Each of the three treatment groups consisted of four pond units. Three reserve ponds (one per group) mitigated mortality losses throughout the experiment. Consequently data was collected from nine pond units (Table 4). Simple Random Sampling characterized the assignment of stock to the pond units following Musita et al. (2021). Tests for selected water parameters in pond units were conducted throughout the experiment. Apart from water temperature where a cylindrical mercury thermometer was applied, all parameters were tested using the Lamotte water test kit following Ajibonge et al (2015). Values for water the parameters; Dissolved Oxygen, ammonium-nitrogen and nitrite-nitrogen in treatment groups are summarized (Table 3).

The Two-stage Cluster design was applied in the three commodity markets of survey site A. It aimed at test feed valuation based on ingredient prices in local commodity markets. (Table 1).

Table 1. Description of local commodity markets of survey site A

\begin{tabular}{lllll}
\hline Commodity market & $\mathrm{Cl}$ & $\mathrm{Sf}$ & $\mathrm{Fi}$ & $\mathrm{Su}$ \\
\hline Main market & $\mathrm{A}$ & 15 & 4 & 20 \\
Millers market & $\mathrm{B}$ & 12 & 1 & 5 \\
Veterinary input market & $\mathrm{C}$ & 8 & 1 & 5 \\
\hline
\end{tabular}

$* \mathrm{Cl}=$ code letter, $\mathrm{Sf}=$ sampling frame, $\mathrm{Fi}=$ feed ingredients, $\mathrm{Su}=$ sampling units.

The size variations in commodity markets were reflected in the sampling frames. Clustered retail shops that characterized the commodity markets rendered Two-stage Cluster Sampling appropriate for selection of sampling units. Non-random and random samplings were applied following Bob-manuel and Erandu (2010). The initial stage involved the non-random selection of six clusters corresponding to the number of targeted feed ingredients. The second stage involved random selection of five sampling units from each of the sampling frames. Data on ingredient prices was collected from the 30 sampling units (Table 4) after every 28 days during the 16 week survey (March to July 2016).

The Linear Systematic Sampling and Design was applied along the main roads network of the study area. It aimed at output valuation based on prices of the experimental fish in local markets. Linear Systematic Sampling following Farm Products Prices Survey (2016) was applied for the selection of the five sampling sites at survey site B. Subsequently, the following sampling units were selected from a sampling frame of trading along the main roads network; Mayuge, Bugembe, Kamuli and Busembatia. Data on retail prices Nile tilapia from the fisheries of Lake Victoria and Kioga was captured from two non-randomly selected retail shops at each of the 
sampling units. Six samples were collected periodically after every 14 days during the eight week sample survey.

\section{Proximate Analysis and Formulation of Test Diets}

A dried and powdered sample was scooped from each of the sisal bags containing 100kilograms of a specific feed ingredient. Guided by Abdulrazak et al., (2014), proximate analysis for the ingredients (Table 2) took place at the Faculty of Agriculture of Makerere University prior to test feed formulation.

Table 2. Proximate analyses for selected nutrients in the feed ingredients

\begin{tabular}{lcccc}
\hline Dietary nutrients & \multicolumn{4}{c}{ Composition in formulated test diets (\%) } \\
\hline & PNM & MPM & FM & MB \\
Crude Protein & 55.16 & 44.5 & 38.68 & 6.8 \\
Crude Fat & 35.07 & 29.81 & 4.58 & \\
Crude Ash & 2.82 & 3.26 & 20.15 & \\
\hline
\end{tabular}

*PNM=peanut meal, MPM= mixed plant meal, $\mathrm{FM}=$ fish meal, $\mathrm{MB}=$ maize bran

There were three test diets; fishmeal (FM)-based diet and two peanut-based diets; peanut meal (PNM) based diet and mixed plant (MPM) based diet. During formulation of the FM and PNM-based diets, sole protein sources were used at 100\% inclusion level while The MPMbased diet contained combined protein sources: (PNM and (SBM) in a ratio of 50: 50.

The Pearson Square Method standardized the Crude Protein (CP) contents of test diets. During the first rationing phase (RP) (12 weeks after stocking), test diets were standardized to $30 \%$ CP. Due to declining demand for protein as fish grows, the CP content reduced to $25 \%$ until end of the feeding trial. Prior to mixing, a top loading electronic balance (version 3.1, 2009) weighed the ingredients. Daily Feeding Ration (DFR) of $5 \%$ of mean body weight of the experimental fish was used following Nandal and Pickering (2004). The fish fed twice daily at 9.00 am and 5.00 Adjustments in DFR occurred after every 28 days till end of the feeding trial.

A Total Feed Ration equivalent to 15,800 grams was consumed per pond unit.

\section{Calculations for Indicators of the Input and Output Valuations}

The indicators for input-farm output valuation and profitability during the feeding trial were calculated following the procedure of El-Saidy and Gaber (2003);

a) $\mathrm{FB}=\mathrm{W} 1+\mathrm{W} 2 \ldots \ldots .+\mathrm{W} 48$. Where;

$\mathrm{FB}=$ fish biomass ( $\mathrm{g} /$ pond -$)$

$\mathrm{W}=$ Weight of fish $(\mathrm{g})$

b) $\quad \mathrm{FBl}=\mathrm{FB}-\mathrm{FBg}$. Where;

$\mathrm{FBl}=$ loss of fish biomass during the in experiment (g/pond-)

$\mathrm{FB}=$ fish biomass ( $\mathrm{g} /$ pond -$)$

$\mathrm{FBg}=$ gain in fish biomass (g/pond-)

c) $\quad \mathrm{UCf}=$ PCi1 + PCi2 $+\ldots \ldots \ldots+$ PCi4. Where;

$\mathrm{UCf}=\mathrm{Unit}$ cost of feed/cost of one kilogram of the feed (USD)

$\mathrm{PCi}=$ partial cost of ingredient (USD)

d) TCf $=$ UCf $x$ TFR. Where;

TCf $=$ total cost of feed (USD)

$\mathrm{UCf}=$ unit cost of feed (USD) 
TFR $=$ total amount of feed ratio per pond throughout the experiment $(15,800 \mathrm{~g})$

USD $=$ United States Dollar

e) $\quad \mathrm{FP}=\mathrm{FBm} X \mathrm{PWm}$. Where;

$\mathrm{FP}=$ farm-gate price (USD)

$\mathrm{FBm}=$ mean value of fish biomass (g/pond-)

$\mathrm{PWm}=$ mean value of unit price of wild Nile tilapia (USD)

f) $\quad$ PI $=$ FPm /TCf. Where;

PI= Profit Index

$\mathrm{FPm}=$ Mean value of farm-gate price of Nile tilapia in sapling sites (USD)

$\mathrm{TCf}=$ Total cost of feed input in per pond by end of the experiment (USD

One-way Analysis of Variance (ANOVA) revealed a significant difference $(\mathrm{p} \leq 0.05)$ among the three group means following Opiya et al (2014). Guided by Amisa et al. (2009), the Turkey's Honestly Significant Difference (HSD) determined the significantly differently $(\mathrm{p} \leq 0.05)$ paired $\mathrm{PI}$ values using the formulae; $\mathrm{HSD}=\mathrm{q} \sqrt{\mathrm{MSE}} / \mathrm{n}$. Where; $\mathrm{q}=$ studentized range test; $\mathrm{MSE}=\mathrm{Mean}$ Square of Error; $\mathrm{n}=$ number of observations in a treatment group.

\section{Results}

Data on proximate analysis, water parameters and feed ingredients, water parameters and fish biomass production, feed costs and farm gate prices have been indicated in the results. Both the protein and basal supplements were analysed as indicated (Table 2). There were significant variations $(\mathrm{p} \leq 0.05)$ in water parameters across dietary treatment groups for $\mathrm{DO}, \mathrm{pH}, \mathrm{NH}^{3}$ and $\mathrm{NO}_{2-}$. No significant difference $(\mathrm{p} \geq 0.05)$ in mean values occurred in water temperature across the groups (Table 3). Biomass production and loss across dietary treatment groups are indicated (Table 4). The feed input and farm output values and profit indices are shown in Table 5.

Table 3. Mean values of selected water quality parameters of treatment groups at the experimental study sites

\begin{tabular}{llllll}
\hline DT & Temp. $\left({ }^{\circ} \mathrm{C}\right)$ & $\mathrm{DO}(\mathrm{mg} / \mathrm{L}-)$ & $\mathrm{pH}$ & $\mathrm{NH}^{3}(\mathrm{mg} / \mathrm{L}-)$ & $\mathrm{NO}_{2^{-}}(\mathrm{mg}-\mathrm{L})$ \\
\hline D1 & $28.0 \pm 0.6^{\mathrm{a}}$ & $4.0 \pm 0.1^{\mathrm{b}}$ & $7.0 \pm 0.15^{\mathrm{b}}$ & $1.8 \pm 0.125^{\mathrm{b}}$ & $0.05 \pm 0.003^{\mathrm{b}}$ \\
D2 & $27.9 \pm 0.5^{\mathrm{a}}$ & $6.0 \pm 0.5^{\mathrm{a}}$ & $8.0 \pm 0.25^{\mathrm{a}}$ & $1.5 \pm 0.15^{\mathrm{a}}$ & $0.025 \pm 0.001^{\mathrm{a}}$ \\
D3 & $27.3 \pm 0.4^{\mathrm{a}}$ & $6.0 \pm 0.25^{\mathrm{a}}$ & $8.0 \pm 0.05^{\mathrm{a}}$ & $1.5 \pm 0.075^{\mathrm{a}}$ & $0.025 \pm 0.008^{\mathrm{a}}$ \\
\hline
\end{tabular}

*DT=dietary treatment, D1=Fishmeal-based diet, D2= Peanut meal-based diet, D3=mixed meal-based diet, Temp=Temperature, $\mathrm{DO}=$ Dissolved Oxygen, $\mathrm{NH}^{3}=$ Unionized ammonia, $\mathrm{NO}_{2}-=$ Nitrite nitrogen. Pairs of group means having a different subscript denote that the values are significantly different $(\mathrm{p} \leq 0.05)$ and vice versa.

Table 4. Fish biomass in ponds of dietary treatment groups during the 16-week experiment

\begin{tabular}{|c|c|c|c|c|c|}
\hline \multirow[t]{2}{*}{ DT } & \multirow[t]{2}{*}{$\begin{array}{l}\text { FBlm } \\
\text { (g/ pond-) }\end{array}$} & \multicolumn{3}{|c|}{$\begin{array}{l}\text { FBg } \\
\text { (g/ pond-) }\end{array}$} & \multirow[t]{2}{*}{$\begin{array}{l}\text { FBm } \\
\text { (g/ pond-) }\end{array}$} \\
\hline & & p1 & p2 & p3 & \\
\hline D1 & 539 & 6293 & 6218 & 6319 & 6207 \\
\hline D2 & 404 & 5403 & 5276 & 5366 & 5348 \\
\hline D3 & 419 & 6005 & 6049 & 6095 & 6049 \\
\hline
\end{tabular}

$\mathrm{DT}=$ dietary treatment, $\mathrm{FBLm}=$ mean of fish biomass loss, $\mathrm{FB}=$ fish biomass, $\mathrm{FBm}=\mathrm{mean}$ of fish biomass, $\mathrm{g}=$ grams, $\mathrm{D} 1=$ fishmeal-based diet, D2= peanut meal-based diet, D3= mixed plant meal-based diet. 
The PIs of test diets varied among pond units and treatment groups as indicated below (Table 5).

Table 5. Determination of Profit Indices of Nile tilapia fed on test diets

\begin{tabular}{llllll}
\hline DT & UCf(USD) & $\begin{array}{l}\text { TCf } \\
\text { (USD) }\end{array}$ & $\begin{array}{l}\text { FP } \\
\text { (USD) }\end{array}$ & $\begin{array}{l}\text { FPm } \\
\text { (USD) }\end{array}$ & PI \\
\hline D1 & 0.300 & 4.71 & 19.8 & 20.8 & 4.41 \\
& 0.296 & 4.65 & 22.1 & 20.8 & 4.47 \\
& 0.287 & 4.51 & 21.3 & 20.8 & 4.61 \\
& 0.275 & 4.30 & 22.8 & 20.8 & 4.82 \\
& 0.293 & 4.58 & 18.0 & 20.8 & 4.53 \\
& 0.352 & 5.53 & 16.9 & 17.7 & 3.20 \\
D2 & 0.371 & 5.82 & 18.9 & 17.7 & 3.04 \\
& 0.366 & 5.74 & 18.1 & 17.7 & 3.08 \\
& 0.361 & 5.66 & 19.4 & 17.7 & 3.12 \\
& 0.379 & 5.94 & 15.3 & 17.7 & 2.98 \\
D3 & 0.281 & 4.40 & 19.3 & 20.3 & 4.60 \\
& 0.285 & 4.46 & 21.6 & 20.3 & 4.53 \\
& 0.275 & 4.32 & 20.7 & 20.3 & 4.68 \\
& 0.267 & 4.19 & 22.2 & 20.3 & 4.84 \\
\hline
\end{tabular}

*DT=dietary treatment, D1= Fishmeal-based diet, D2= Peanut meal-based diet, D3= mixed plant meal-based diet, $\mathrm{USD}=$ United States dollar, $\mathrm{TCf}=$ total cost of feed, $\mathrm{FP}=$ farm-gate price, $\mathrm{FPm}=$ mean value of farm-gate price, $\mathrm{PI}=$ Profit Index.

The MPM-based diet exhibited the highest mean PI (4.624) among test diets. The order of mean PIs in a descending order was as follows; MPM-based diet> FM-based diet (4.568) $>$ PNM-based diet (3.084). According to the ANOVA test, the calculated F-value was 1,033.4 while the Critical F-Value in the distribution table at@ $0.05 ;(2,12)$ was 3.88. Since the F-test statistic was less than the Critical Value, it indicated a significant difference among mean PIs. Subsequently, the null hypothesis was rejected.

The difference among PIs for DI and D3 was lower than the Turkeys HSD implying an insignificant difference the paired means $(\mathrm{p} \leq 0.05)$ (Table 6$)$. Other differences among paired group means; D1 \& D3 and D2 \& D3 were higher than the standard value and consequently significantly different $(\mathrm{p} \leq 0.05)$.

Table 6. Comparison of differences in paired mean Profit Indices with the Turkey's Honestly Significant Difference in Nile tilapia fed on test diets

\begin{tabular}{llll}
\hline Comp. & \multicolumn{3}{c}{ Pairs } \\
\hline Tg & D1 \& & D1 \& & D2 \& \\
& D2 & D3 & D3 \\
$\overline{\mathbf{X}}$ & $4.568 \&$ & $4.568 \&$ & $3.084 \&$ \\
Diff. in $\overline{\mathrm{X}}$ & 3.084 & 4.624 & 4.624 \\
Diff. in $\overline{\mathrm{X}} \&$ HSD & 1.484 & 0.056 & 1.54 \\
& $1.484 \mathrm{a} \&$ & $0.056 \mathrm{a} \&$ & $1.54 \mathrm{a} \&$ \\
\hline
\end{tabular}


*Pairs of group means in the same row having a different subscript denote that the values are significantly different $(\mathrm{p} \leq 0.05)$. Comp. $=$ comparisons, $\mathrm{Tg}=$ treatment groups, Diff. $=$ Differences, $\mathrm{HSD}=$ Honestly Significant Difference. D1=fishmeal-based diet, D2 =peanut-based diet, D3 =mixed plant meal-based diet.

\section{Discussion, Conclusion and Recommendation}

Although there were variations, including significant differences $(p \leq 0.05)$ among water parameters across treatment groups; temperature, $\mathrm{DO}, \mathrm{pH}$, and $\mathrm{NO}_{2}$ - fell in acceptable ranges for proper growth and survival of cultured Nile tilapia. The recommended and safe water quality limits for Nile tilapia growth and survival; $\mathrm{NH}^{3}$ (0.01-0.029), $\mathrm{NO}_{2-}(0.46 \mathrm{mg} / \mathrm{L}), \mathrm{pH}$ (6.6-7.2), DO (6.1-7.2 $\mathrm{mg} / \mathrm{L}$ ) and temperature $\left(26-30^{\circ} \mathrm{C}\right.$ ) (Hargreaves \& Tucker; 2004) implying that ranges for the majority of tested parameters did not significantly affect performance in Nile tilapia due to maintenance of appropriate culture conditions for the experimental fish. Only $\mathrm{NH}^{3}$ that accumulated above the recommended range induced a higher biomass loss that positively correlated with the compound level. The findings conform to the study of Olapode and Quinn (2019) where fish mortality was attributed to the high level of $\mathrm{NH}^{3}$.

The proximate analysis confirmed that the test ingredients were protein supplements since they contained more than 20\% Crude Protein content apart from maize bran (Table 2). According to Robinson et al. (2001) protein sources in fish diets should contain at least $20 \%$ of Crude protein. Despite the lack of a significant difference $(\mathrm{p} \leq 0.05)$ among mean PIs, the MPMbased diet exhibited a higher PI than the FM-based diet. Other investigators obtained similar results from comparisons of combinations of plant-based ingredients as alternatives to fishmeal in aqua feeds. For example in the study of El-Saidy and Gaber (2003) a mixture of soybean meal, cottonseed meal and sunflower meal fed to Nile tilapia as FM substitute produced the highest PI at 100\% replacement level. Basing on field data (Table 4), the mean total cost of feed equivalent to 4.38 was the lowest among test diets. Although harvest size and farm-gate price contributed, the low cost of the MPM-based diet accounted for the superiority in performance.

The above observation concurs with the following; the significantly higher $(p \leq 0.05)$ PI obtained on the study of African catfish (Clarias gariepinus) by Jimoh et al. (2013) was a consequence of the low cost watermelon seed (Citrullus lanatus) based meal. Risk management in aquaculture studied by Nwanna (2003) reported that high farm profit margins are derived from least cost fish feeds. In addition, Coyle (2004) and Ahamed (2013) stated that cheap feed enables fish farms to retain high net profits. The above findings partially contradict the trial on oil-seed meals where a combination of low cost and good growth performance in Nile tilapia. Furthermore, they totally inconsistent; Hassan (2007) who concluded that product-gate price is the most important variable influencing profit margins on fish farms and the study by AbouZeid (2015) where the higher PI was largely attributed the price of farmed Nile tilapia.

Contrary to the MPM-based diet, cost of diet and poor water quality negatively affected the performance of the FM-based diet. Although investigators largely pointed at high feed cost; Okumus and Mazlum (2002), Diaal-kenawy, et al. (2008), Bob-manuel and Erondu (2010), lowered profitability in pond raised fish fed on dietary fishmeal may link to reduced yield due to rapid the accumulation of toxic ammonia. According animal-derived ingredients including fishmeal are more prone to decomposition (Themelis, 2005) implying that they can readily release $\mathrm{NH}^{3}$. The findings are consistent with The findings are consistent with Onada et al (2015) who attributed the high fish mortality in earthen ponds to increased level of $\mathrm{NH}^{3}$. 
The FM-based diet exhibited a significantly higher $(\mathrm{p} \leq 0.05)$ PI compared to the PNM-based diet. Performance of the PNM-based diet was significantly poorer $(\mathrm{p} \leq 0.05)$ than all other test diets. Similar results were reported by the following; the study by Abirike et al. (2014) which indicated that PI was significantly higher $(\mathrm{p} \leq 0.05)$ for the FM-Pito mash mixture than FMPNM mixture. Test diets fed to Nile tilapia by Agbo et al. (2011) where PI was higher for the FM-based diet than PNM-based diet. Other related investigations have reported contradictory results. In the study on cost-effectiveness analyses for the common carp (Cyprinus carpio L.) diet, by Hassan (1991), profitability was higher for the PNM-based diet than FM-based diet. In addition, the investigation of Agbo et al. (2011) indicated a higher PI for PNM than 'all fishmealdiet'. The higher diet cost coupled with lower farm-gate price for Nile tilapia accounted for the lowest PI of the PNM-based diet during the current study. The above statement is consistent with the investigations on cultured Nile tilapia by Opiyo et al. (2014) and Anani et al. (2017) where high feed costs without commensurate increase in the fish prices lowered the PIs of fish diets.

The MPM-based meal that exhibited the best performance in terms of PI should completely substitute dietary FM in pond cultured Nile tilapia. By virtue of its relatively poor performance, the PNM-based meal should be restricted to partial substitution of FM in the Nile tilapia diet.

\section{Acknowledgement}

The authors wish to thank the staff of the Department of Fisheries and Natural Resources of Maseno University for their academic guidance throughout the study.

\section{References}

Aanyu M. \& Graber A. (2010). Enhancement of aquaculture productivity, profitability and marketing for improved nutrition and income in Uganda. Aquaculture Research and Development Centre, Kajjansi, Kampala, Uganda. 1-8.

Abdulrazak S., Otie D. \& Oniwapele Y. A. (2014). Proximate analysis and anti-nutritional factors of groundnuts and melon husks. Journal of Animal and Feed research, Vol. 4, Issue 2; 25-28.

Abirike E. D., Atsu C. F., Al-Hassan E. H. (2014). Novel feed for fingerlings of Nile tilapia (Oreobromis niloticus L.). Journal of Biological Science, 1(4) 25-29.

Abou-Zeid R.M. (2015). Effect of diet extrusion on growth performance, feed utilization and economic efficiency of Nile tilapia on commercial arms. Egyptian Journal of Nutrition and Feeds, 18 (1) 143-150.

Agbo N. W., Adjei-boateng D. \& Jauncey D. (2011). The potential of groundnut (Arachis bypogeal L.) by-products as alternative protein sources in the diet for Nile tilapia (Oreochromis niloticus L). Dept. of Fisheries \& Water shed management, Univ. of Kumasi, Ghana. 23-31.

Agricultural Planning Department. (2010). Statistical Abstract. MAAIF, Entebbe, Uganda. 23, 41.

Ahmed A. A. (2013). Effects of stocking density and feeding levels on the growth and survival of Nile tilapia in earthen ponds. Journal of Agriculture \& Veterinary sciences, Vol. 14; 95 101.

Ajibonge O.O, Qari R., Yakubu A.F. (2015). Growth performance in Nile tilapia (Oreochromis niloticus $L$.) reared in glass aquaria under different treatments and durations. International Journal of Biology and Biotechnology 12 (2) 203-209. 
Amisa S., Oteng A. \& Ofori J. K. (2009). Growth performance of African catfish (Clariras gariepinus) fed on varying levels of Lencena leucephalata leaf meal. Journal of applied Sciences \& Environment management, Vol. 13; 21-26.

Anani F. A., Nuno F. K. E, Steiner-Asiedu, Nortey T. N. N. \& Agbo N. W. (2017). Evaluation of farm-made and commercial tilapia diets for small-scale Hapa production of Nile tilapia (Oreochromis niloticus L.) in Ghana. Journal of Applied Life Sciences. 10 (3) 1; 1-12.

Bainempaka A. B., Kato H., Mulera D. B., Abwol-Ametto T. (2006). Principles and practices of Agriculture. Macmillan publishers, Kampala, Uganda. Vol.1, 70-89.

Bob-Manuel F. G \& Erondu E. S. (2010). Yeast single protein in the diet of Nile tilapia (Oreochromis niloticus L.) fingerlings; an economic evaluation. African Journal of biotechnology, Vol. 10 (80) 18581-84.

Coyle D. G., Menger G. J., Tidwell J. H. \& Webster C. D. (2004). Evaluation of growth, feed utilization and economics of hybrid Tilapia fed on diets containing different protein sources. Aquaculture Research, 35; 365.

Dersjant-Li Y. (2002). The use of soyprotein in aqua feeds. Fish farm feeding, Koog, Netherlands. 542.

Diaal-Kenawy D. Gamal E. N. \& Mohammed Y. A. Z. (2008). Total replacement of fish meal with soybean meal in the diet of Nile tilapia (Oreochromis niloticus L.) cultured in fertilized ponds. $8^{\text {th }}$ International Symposium in Tilapia aquaculture, 12-19.

El-saidy D. M. S .D. \& Gaber M. M. A. (2003). Replacement of fish meal with a mixture of different plant protein sources in juvenile tilapia (Oreochromis niloticus L.) diets. Aquaculture Research, 34 (13) 1119-1127.

El-Sayed D.M.S.D. (2006). Tilapia culture. CABI Publishing Co. Massachusetts USA. 8-65 pp.

FAO, (2009). Impact of rising feed ingredients prices on aqua feeds and aquaculture production. Fisheries and Aquaculture Tech. Paper No. 541, 63.

Farm Products Prices Survey (2016). Statistics of Canada; Detailed information for January 2016. Ontario, Canada. 12-15.

Gillespie J. R. (2004). Livestock and poultry production. $7^{\text {th }}$ edition, New York, USA. 23-35.

Hassan M. R. D. (1991). Evaluation of some plant ingredients in dietary protein sources for common carp (Cyprinus carpio L.) fry. Fish aquaculture 151; 55-70.

Hassan M., R. (2007). Economics of aqua culture feeding aquaculture practices in selected Asian countries. Fisheries Technical Paper 505, FAO, Fisheries \& Aquaculture Dept. Rome, Italy. $1-34$.

Health \& Nutrition research, (2010). Peanut products; diets and eating patterns. Albany, Georgia, USA. 51-58.

Jimoh W. A., Ayeloja A. A. Rifat A. O. Adeleke A. B. \& Shodamala M. O. (2013). Incidence of cost analysis of producing African catfish (Clarias griepinus) using diets containing water melon (Citrullus lanatus) seed. 3-7.

Kaushik S. J. \& Seiliez I. (2010). Protein and amino acid nutrition and metabolism in fish; Current knowledge and future needs. Aquaculture research, 41; 3320-332I.

Liti D. M., Waidbacher H., Straif M., Mbaluka K. K., Manguti J. M. \& Kyenza M. K. (2006). Effect of partial and complete replacement of fresh water shrimp meal with a mixture of plant protein sources on growth performance of Nile tilapia in fertilized ponds. Aquaculture research, 37; 477-483

Mbahinzireki G. B. (1999). Tilapia (Oreochromis sp.) Sex reversal and performance on alternative sources of protein. PhD thesis, Ohio State University, USA.8-25. 
Meric I. Yildrim O. \& Derm R. (2015). Bio-economic analysis of diets comprised of sunflower meal as a substitution of fish meal in carp diets. Faculty of Agric., Dept. Fisheries \& Aquaculture, Ankra, Turkey. 12-15.

Miles R. D. \& Chapman F. A. (2006). Benefits of fish meal in aquaculture diets. IFAS extension, University of Florida, USA, 3-16.

Mmanda F. P. (2020). Nutritive value and us of locally available low cost feed ingredients for tilapia farming in Tanzania. Doctoral Thesis, Swedish University of Agricultural Sciences.

Moehl J., Halwart D. (2005). A synthesis of the formulated animal and aqua feed industry in Sub-Sabara Africa. No. 26, FAO, UN, Rome. 12-19.

Musita A, A. Ogello E., Balirwa J. S., Otieno C. (2021). Comparison of net fish yields in pond cultured Nile tilapia (Oreochromis niloticus L.) fed on peanut-based meals as alternatives to dietary fishmeal. International Journal of Fisheries and Aquatic Studies, 2021(9) 293-298.

Nandal S. \& Pickering T. (2004). Tilapia fish farming in Pacific island countries. Noumea, New Caledonia. 12-14.

Ngugi ,C. C., Egna H. Oyoo-Okoth E., Manyala J. O. ( 2016). Growth, yield and economic benefit of Nile tilapia (Oreochromis nilotius L.) fed diets formulated from local ingredients in cages. Intern. Journal of Fisheries \& Aquatic Sciences 4(6) 191-195.

Nwanna L. C. (2003). Risk management in aquaculture by controlled feeding regimes. Pakistan Journal of Nutrition, 2 (60), 324-328.

Okumus I., Mazlum M. D. (2002). Evaluation of commercial Trout feeds; feed consumption, growth, feed conversion, carcass composition and bio-economic analysis. Turkish Journal of Fisheries and Aquaculture, 2:100-107.

Onada O., Akinwole A. \& Ajani A. (2015). Study of interrelationships among water quality parameters in earthen ponds and concrete tanks, Department of Aquaculture 7 Fisheries, University of Ibadan Nigeria. 1-5.

Opiyo M. A. Manguti J. M. Ogello E. O., Karisa H. C. (2014). Growth response, survival and profitability of Nile tilapia fed at different frequencies in fertilized earthen ponds. International Journal of Science \& Research, 2319-7064, 893-898.

Peanut Institute (2003). Eat well, eat pea nuts. Albany, Georgia, USA. 1-8.

Robinson E. H., Menghe H. L., Bruce B. N. (2001). A practical guide to nutrition feeds and feeding of catfish. Mississippi State University, USA. 8-13.

Russa J. R. \& Yanong R. P. E (2002). Molds in fish feeds and alfatoxicosis. Fisheries \& Aquatic Science, Univ. of Florida, Florida, USA. 23-27.

Rust M. B., Barrows T. F., Hardy W. R., Lazur A., Waughten K., Siverstein J. (2012). Current situation and prospects on aqua feeds. Dept. of Agric., USDA, USA. 13-14.

Schmidt V., Amarol-Zettler L., Davidson J. \& Good C. (2016). Influence of fishmeal free diets on microbial communities in Atlantic Solomon (Salmo solar) recirculation aquaculture systems. Applied Environmental microbiology. 82 (15). 4470-4481.

The Comprehensive Atlas (2015). Social studies in Uganda 50. Longhorn Publishers (U) Ltd, Kampala, Uganda. 50, 51.

The Fish Site (2015). How to achieve good water quality management in Aquaculture. University of St. Andrews. Ireland. 1-12. 